\title{
N 72229049
}

STIDWUS CONIROL IN PIGBONS AFTER EXTENDED DISCRIITMATIVE TRAITIIT ${ }^{2}$

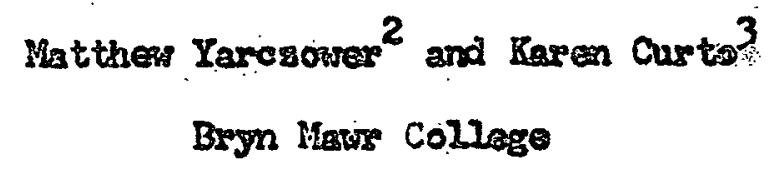

The efrecto of manount of training on cenditioned inibibition and on the degres of stirulus control were studiad using plgeons.

The ebility of an S- assoosated with nenoralnforeswent to supprass positive reinforced boherfor wos ecquired very sapldiy dusing digeriminativs training. Insereased St, S- treining appeared to weken this conditioned Inhibitory ofiect whilo at the age the nore St training apperentily inereased the amount of extiangl inhibstion (nonosonditioned inhibition) of positively reinforeed behavior by a novel atimulus.

Behevioral contragt and Incronentel genaralsestion gredients along the S. dimensien (inhibitory dimsionsl control) were ebrent at all stages of

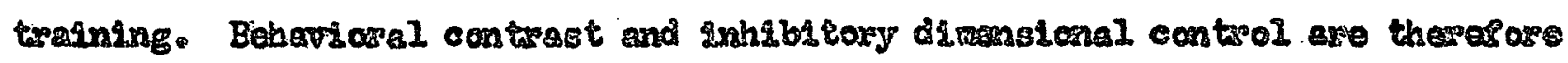
not necessary conconthants of conditioned Inktbithon by an So.

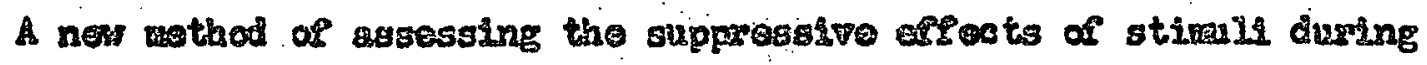
generelization toots was dosertbed. 


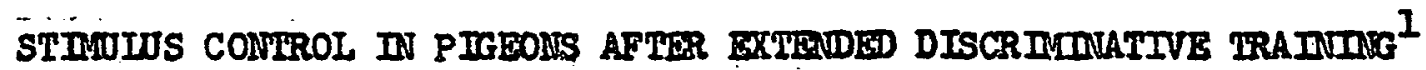

$$
\begin{gathered}
\text { Matthew Yarcsower and Karen Curto }{ }^{2} \\
\text { Bryn Mawr College }
\end{gathered}
$$

The plarpose of the present experinent was to study the offeot of amount of training on the degree of control over key-pocking beherior aequired by each of tro stimulus diwensions in the course of discriminative training. Ifttlo work has been done on the problem, and what data there are do not parmit unequivocal concilusions about the relation botweon stimilus control and arount of tralning (Fapthing and Hearst, 1959; Terracs, 1966; Yarczower. 1970)。

In the first of two experiwonts reported by Terrece (1966). generalization gredients after 60 sessions of diseriminative training revealed neither a displacement in the peak of the gradient nor asymetry in the distribution of responses. In the second experinent, 15 discriminative sessions ylelded peak shifts and asymotrical generallsation gradients; continued discriminative training '60 sessions) elininatod the peak shift but not the asymotrical generslifation gradients. The lack of asymetry in the gradients after extended training in tho pirst experiwent could havo rosultod of thar Prom a lack of inhibitory control by the S- or from highly specific control by the S-. In the second experiment, In witioh asymetrey was st1ll present in the generaliastion gradients aftor 60 sessions of disoriminative training. it is likely that inhibitive control by the S- was atill prosent. Tarrace colild not diretiy test this possibisity, but Farthing et al. (1968) obtained data which led them to suggest that greater smothts diserimingtive training yivids n。. increasing specificity of extitatory control by $\mathrm{S}+$ and inhibitory control by S- .. "(p. 751)。 In any case, thoir dato gavo no reason to beliove that inhibitory control by S- disappesrs of th extonded training. Yaregower (1970), howerer. Peund Plat sunctions in genorslifation tests conducted after behsviors I contrest had boen eliminated, but eloar oridence 
of Inhibitive stimulus control in tests conducted whilo bahavior contrast was still present.

The present experiment was intended to ovido further information sbout both excitatory and inhibitory stiwilis control aftor oxtended diseriminativo training. Ileally in such a study, the S+ and S- dimensions should be orthogonal in order that variations along ono dimension in the

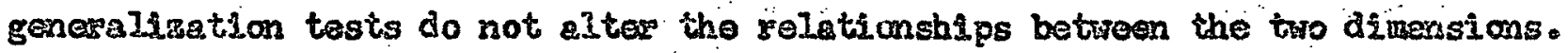
With onthogsnal dimensions. the sidilarity of a stimius on one dimonsion to those on the other dimension is the seme at all points an the dimensions Extended training ylelds such low lovels of yesponding in the presence af the S. that the consequent 10 sates of respoxding in generalisation tegts may render the obteined gradients difficult to interpret. To coubst tbis poblex in the present experiment, stimili on the $S$ - dimansion (Iine toit) rere superimposed on stivalus Prow the St dimenston (color). This procedure. which was intended to inerease the ovirall level of responding during testing. has other Implications which will be considesed later.

HISTHOD

\section{Subjects and Apparatus}

Thenty-three experimentally nairo Silver King pigeons two to three Jears

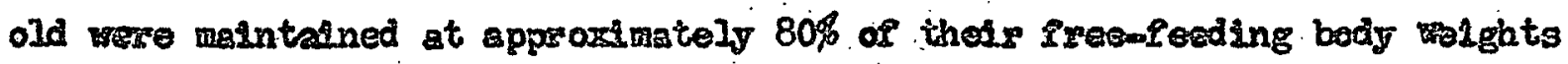
throughout the expinent. The oxperimental chambers were mede of Ploxagles and masured $36 \mathrm{~cm} \times 36 \mathrm{em} \times 38 \mathrm{~cm}$. Tho chamber, within which tho pigeon Was pleced, bras itself within a lapge chaber mado of wood nith Celotor Iining that sitenuated sounds frow outside the chambar. The largor chamber was $38 \mathrm{~cm} \times 43 \mathrm{~cm} x 71 \mathrm{ca}$. The response panel contalned a standard Gerbrands pigeon kit that was medo of clear Plexiglas and behind which wis a pejectore made by Industrial Electronic Enginesss Co., Model No. 10.1279-1829L, that 
could project anj we of nine rhite line tilts and any we of threo colors or any coabination ef color and whito Iine tilt. A Lohlgh Valloy Electronics Co. gain Ieeder was loeated below the resprense key.

\section{Procedure}

A11 pigens rexe wagazine trained on the flust day and given 25 reinforeements on each of tro days in which each koy poek in the presence of a green key-light was followed by access to the food magatine for $3 \mathrm{sec}$.

The birds were divided Into cro groups. an experimental group of 10 bires that received discriminative training and a control group of 13 birds that did not zecoivo disoriminstive training.

Birds in the oxporinentel group begen diseriminative training following the second day diring which osch key peck had been reinforced. A vaxiableinterval (VI) Imin sehedulo of reinforcewent in the presence of a grem boy-light (S+) was altermatod in quast-randow order (Gellerwam, 1933) with an extinction schedule in the presence of a blek key with a 5 wante Ferticel lino (S-). Each seasion consisted of 10 poriads of $S+$ and 10 periods of S- presentetions. The duration of each stimlus pariod was 30 sec. Thero was a 5-gec timout ( 10 ) porlod betwem stimins presentations during which the kay 1igh:s were of and food selnforcess wite not availsblo. The birds in the control group were given 10 periods of St.

Esch group of birds was divided into two subgroups whioh differed froth ano another with respoot to whon genoraliwation tosts wero firgt given. For ono sabgroup. generalization tests wero carried ou aftor oach of three stages of troining: early (after one session); middlo (after 25 sesstans); and late (after 60 sessions). The other subgroups gas given generalization tests after only two steges of training, middlo and late. Generelization 
teste consisted the prasentation of nino test stiull: gren (the St during training), orange, red, a vertical white line on a dark backgeound (the So Ior tho birds of the experibental group) and IIve different white line orientations (voritcel, 40 and 80 degrees to the loft and right or verticel) on a green beckground. Stibulas presentations were separeted by 5 see To period and were 30 see in duration. Foed reinforcers nere unatrilablo during tho gineraligetion tests. Each one of the nine test stimuli was progented six tires for a total of 54 test trials.

$$
\text { RRSUIIS }
$$

Fig 1 shows the ween response retos for the subgroups of birds tested aftor each of three stages of training. Mean response sates in the presence

\section{Insert Fig 1 about have}

of $\mathrm{S}+$ increased algnisicantiy with training. Although the rean respanse.

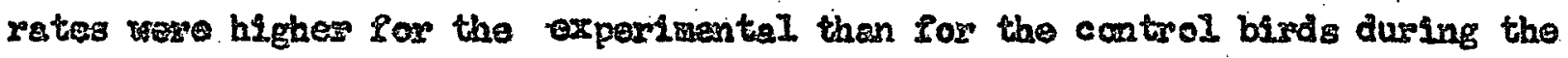
flrst 27 sessions, the differences between the groups were not statisticeliy significant $(\underline{Q}>0,05)$ as oviluated by a sepeated measures andiysis of raplance (Bruning and Kanti, 1968)。

The uppor panel of Fig 2 shows the nean number of responses extited during generelizetion tests with the S+ dimensen (odor) Po both the exponimental and the oontrol birds. A ropeatod measures analyeis of variance

\section{Insort Fig 2 gbout bere}

of those absoluto seoses piolded $F$ gatiog thet were statistically signifleant

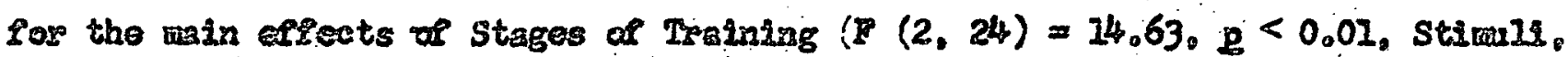
$F(2,24)=47.14, \mathrm{~g}<0.001$ and sor the intersetion of Stage wh th Stirals, $F(4,48)=14,05, \mathrm{~g}<0.001$. Thus, thero wes a significant inerease in the 
totel number of rosponses omitted during generelization tests with inoreased training (Staged); a signisicant genexalfiation gradient (Stivali) ; and a signipleant ohenge in the shope of the genopilisation gradients if th increased training (stage I Stimuli intersetion)。 In addition, an anafyeis of the reletive generollsztion gesdients (per cent of totel pespenses) shown in the lower postion of Figg 2 yiolded a significant Group $x$ Stimals interaction, $F(2,24)=6.29, g<0.01$, which indseates that the velative genersilisation gradients for the experiments l birds was ateepore than for the control birds. In this analysis, es in that for the absolvite nuber of responses, the wain

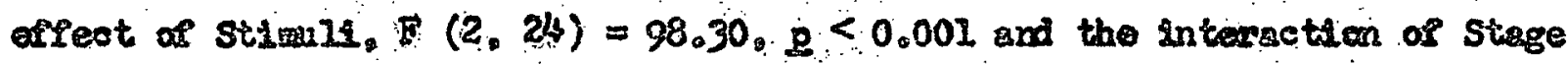
with Stivili, $F(4,48)=3.16, \mathrm{~g}<0.025$, were both signiflent.

If inhibitive gtimalis is one that " .. derelops duetng condstioning

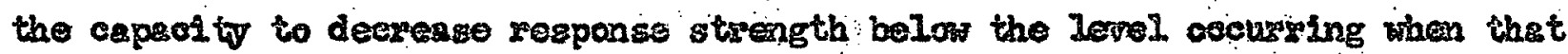
stimarlus is absent" (Hoarst, Besley, and Farthing, 1970, po 376), then 16 showld be passible to messuse the dagre to whioh a atimalus has acquired Inhibitivo properties by the exient to which it suppresses operant beherios during generalization tosts. In the present study suppression of behavior during tests of genesaltgation was weared by tho decroment in responding to a green loy light (St) produced by tho superiuposition al a line tilit (St). The smount of suppression was arleulated the retio $\mathrm{A} / \mathrm{A}+\mathrm{B}_{0}$ in mieh $\mathrm{A}$ sefers to the number of zesponses to the green looy-light with saperimposed line tilt, and $B$ to the number of stesponses to the green bay-ifight alosse (st). With medrat suppsession the zatio is 0.00 ; with no suppression it is 0.50 . Ratios then 0.50 indicato more respaning to a lino th then to the St alone.

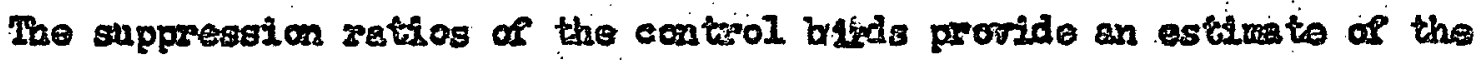
disxuptive ffects of the introduction of line tilt independentiy of an 
property of line tilt acquired in training. The differanoo in suppressica 28tios botaren the experimental and control birde provides an index of the

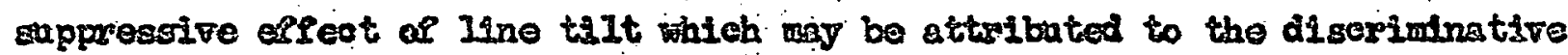
tratining girea the oxporimental enimalo.

\section{Ingsat Fig 3 about hare}

The auppression ratios auring gonesalifation toots produced by the two treinIng procesures aro ghom in Fig 30 Tho wajo difference botwen the two procedures seens to be errij in training, at which point the inhibitive affects of the Sopper to be madiral. A repeated measures analysis of varianos of the suppressien satios yolded a signfioant Groups asect. $F(1,12)$ $=7.88, \mathrm{p}<0.025$ and an intarseties of training pocedures (Graps) bith amount of training (Stages) sihioh was of enjy masginal signisicance, $F(2,24)$ $=3.00 .0 .05<\mathfrak{g}<0.10$. A me-tailed test (Bruning ot 1... 1968, p. 112) of tho difference botreen tho tiro groups early in training gteided a gignificent difrerence $(\mathrm{p}<0.05)$. Differences in moan suppression ratiog botween the two groups at asch of tho other gtages of training zare not statistlcally significant the gane test. It 1 s possible that the lock of significant difPorences between the two groups at tho aidd lo and Iater stages of training

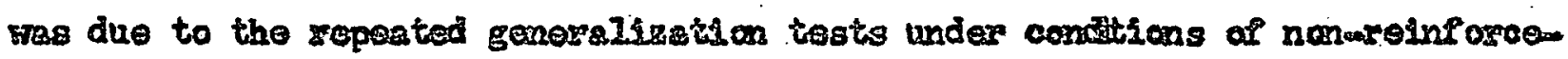
ment which rey haro pecduced a greator decrement in responding for the hirds given cis St tesining then for the bixds given discriminativo training. Fig 4

\section{Insert Fig 4 ebout hero}

dopiots the suppression gatios for tho toro growps of birds wich nore not given generalleation tosts of Variance of tho supprossicen ratios jielded algnifloant Groups effect, $F(1,7)=7.36, \mathrm{~g}<0.05$. Nol ther tho effeot of stinuis nor the Interaction of Strolis z Groups were statistically signifleant. Dirferences 
In suppression produced by the two treining procedures ware therefore present aiter the early sieges of training for birds tostsd firgt at the middlo stage of training.

\section{DISCUSSION}

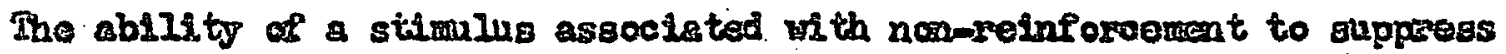
bohovior can be aequired quito reapidiy during disoriminative training. In the present sturdy, the So bocame "inhibitory stimulus" (Hearst ot el., 1970) aftor the first session of disoriminative training wich had consisted dif sivo minutos axposure to the S-. Taken as a wholo, the ganeralisation tost dats gupport the ouggertion that the inhibitory pioperty the S- was toaned with further tralning. Although the sbisolite laval of behavioral inbibition increased (the cuppossion ratio docreased) whth further training, it did not ineresse differenthelly for the two groups. Suppression of bebsition by the novel stimins (the S- for the disoriminativo training group) incroesed th further training far the birds in the control group. This inorease in auppression was corrolated with Increased ratos of responding to the S+ and with sncrossed exaltatosy dinensional control (storger generalization gradientis along the St dimensten). This inhibition is meso proporiy labollod "extarnal inhibition"i: Inhibition pacoluced by disosiminativo treining (conditioned inhsibition). bes

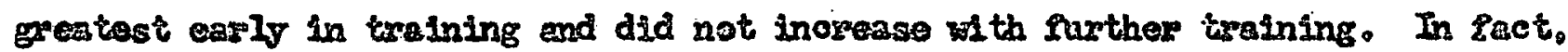
it would appese that conditiened inhlbition (se reflooted by the discerences In suppression betsean tho two treining procodures) deareased with further training. "Inhibitary dimengional control" (Hesrst ot alo, 1970) wes absent st all gteges of disomitutive training. 1.0., variation along the Ine thit

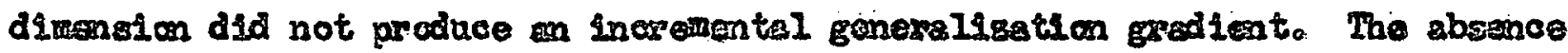
of almenstonal sontrol by the line tilt dimention prealides a couparison

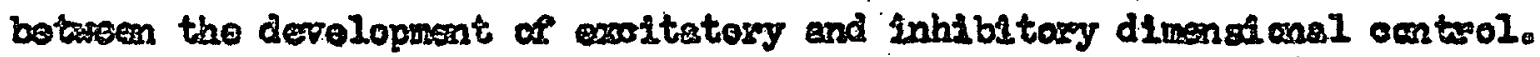

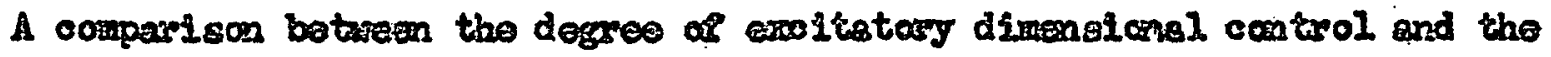
cenditioned inbibitary propepty of Sw suggests that they mave baen negatively 
complated. Suppression by tho $S$ wo worngl early in training and

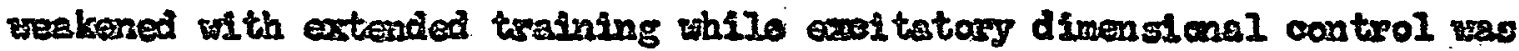
reak eariv in training but inereased with oxtended training. A number af Intarpetations of different pieots discringtingte tralning have empasibed the cititical nature thst S- responding plays in producing theso eflects (Terrese, 1971; Weiss, 1971; Yoscrower, Dioken and Golinb, I966). It ghould be noted however that changes in the inhibitory property of the 5 were unaccompanied by changes in the levels of S responding. Responso ratos. in S- were at the winimal level alnost at the beginning of disoriminative training.

The results of the present study bear some similarity to those reportad by Datis (1971). In that study. birds given discriminative taraining yielded no Imbibitory dimenglonal control. Davis also reported that the Sm suppressed behavios although it was not posstble to assoss how who of tho sesponse decramt was due to tho discriminative treining and how whe wis to extornal Inhibition or to a generaligation deorenont produced by novel stimins.

Finally, incresed discrinative twining has sometiwes oliminsted bobavios contrast (Tastaco, 1966; Yesenowas. 1970) and serotimes not (Hoarst, 1971)。 When bahoviorel contrest bos besn reduced or olimingtad,

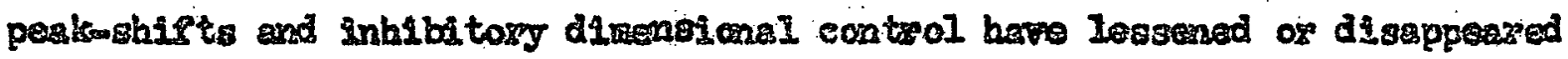

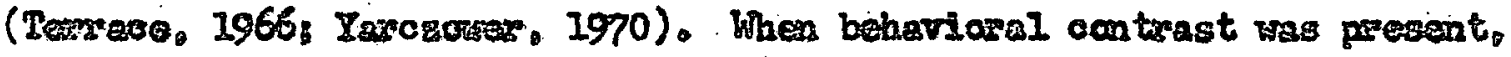

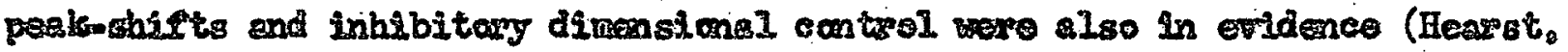

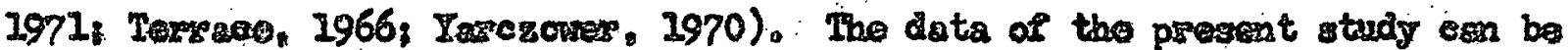

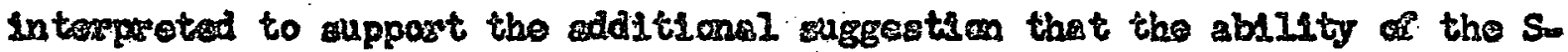

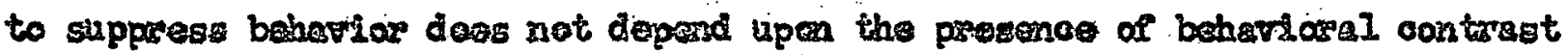
(as assoased by ecmparisen of $5+$ retos botroen tho control and expordmental groups) nor upen tho peesmae of inbibitary dimenstonal control. 


\section{RES EREYCES}

Buning, Jo I. and Kinta. B. I. Comptational Hondbogl of Ststistica. GIenvies, DIInols: Scott, Foresmen, 1968.

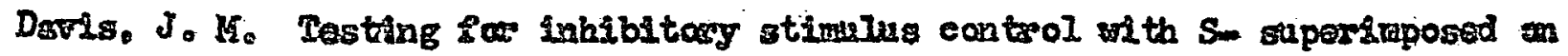

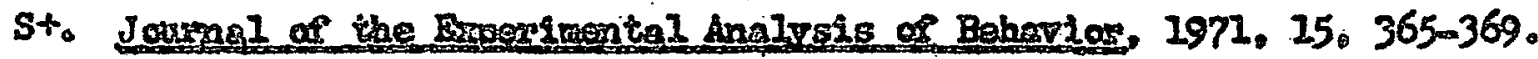

Deutseh. J.A. Diserintinatien Iearning and inhibitien. Sesence. 1967. 156. 988. Fartising. G. Wo, and Hearat, E. Gerioralization gradients of inhibition after

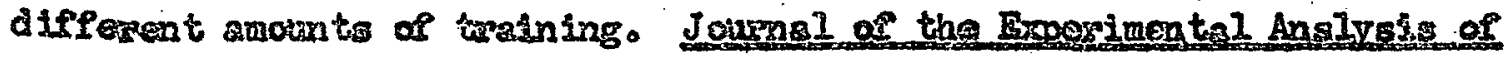
Echarjog: 1968, 11, 743.752.

Gollermann. I. Wo Chance orders of eltemating stimuli in visual discrintnation

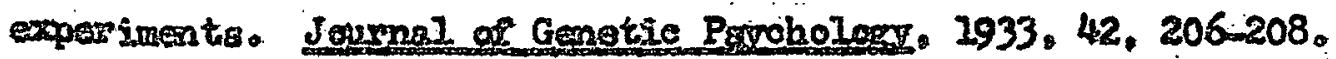

Bearet, Fo Contrast and stimins genoralisation following prolonged disorimo

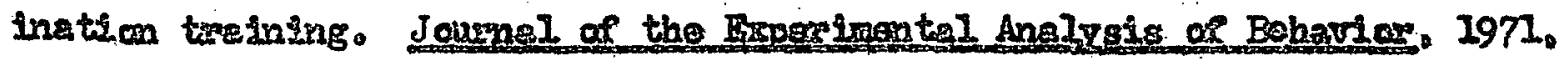
15. $355 \mathrm{~m} 363$.

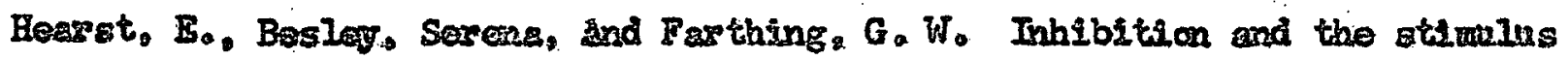
contgol of operant behavior. Jaunal of the Expexinental Ans 7 sis of Beheger. 1970, 14, 373-409.

Terrace, H. S. Behavierel contrest and the peak shift: oflects of axtended

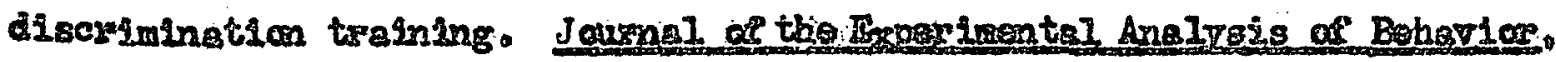
1966, 9.613m617.

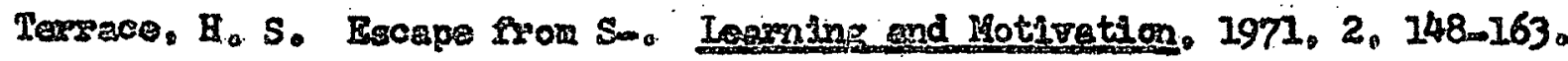
WeLs, S. Jo Digegimingtion twaining and stiming compounding: constaration

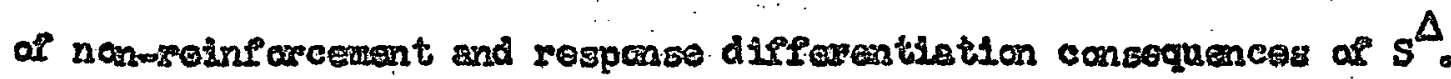

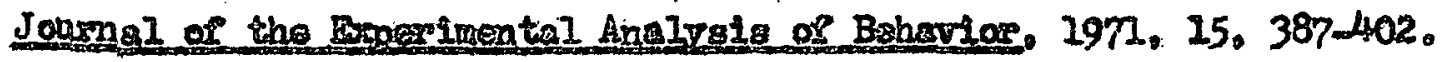

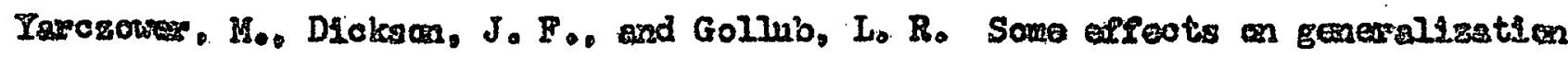

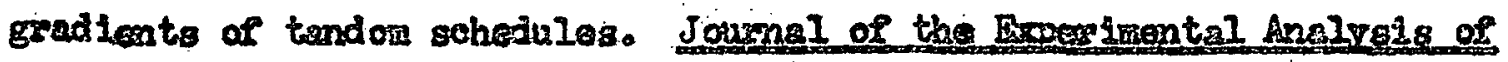
Boheriog, 1966, 9,631-639.

Iarczower. Me Beharioral contrast and inhibitive etianins control. Perchonomic Solenog. 1970, 18, $2-3$. 
Yarczowsers and Curto

\section{FOOTHOTES}

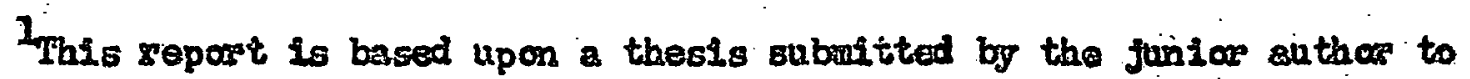

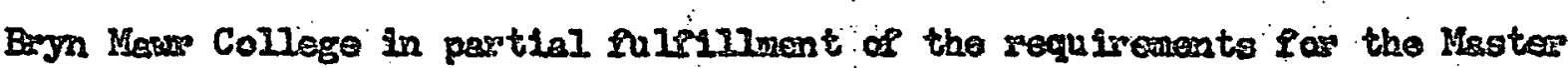
of Arts degres. The athors are indebted to Ra C. Gonealos for a apitiesI

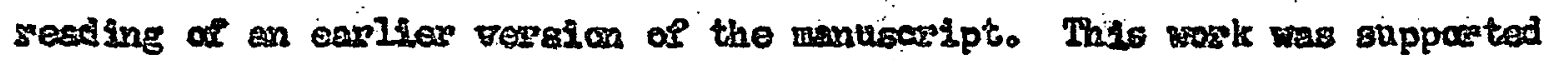
by HASA Crant NGR-39-038.002。

Requests tor reprints should bo sent to hather Yarezowes, Departmeat

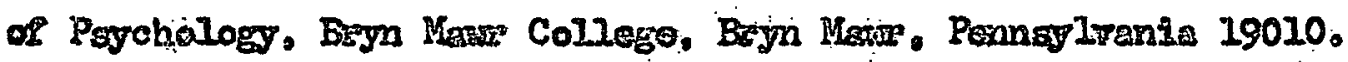

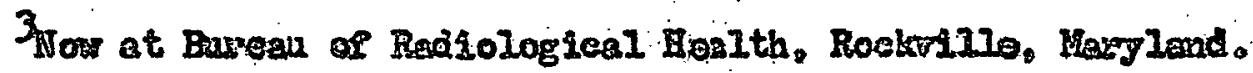


Tarozorer and Cunto

CAPITONS FCR PITURES

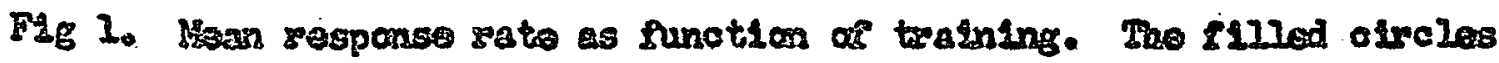
with solid Iino are the ratos in $S+F$ the group given $S+$. So training. The

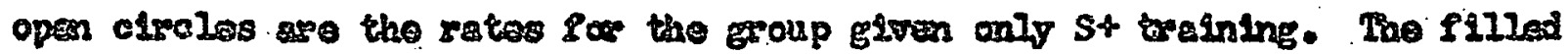
eipcles orth the dottad Inn are the sates in So Iap the group given St, S. thelnging.

Fig 2. Tho upper panal, contains tho absolute genearelisation gracients along the St dimension (color) at different stages of treining for the group given St, S. training (filled clroles) and for the gxoup given oniy St training (open circles)

The low panel centains the pelative genssoliation gradiento based upon the sane data as sboin in the upper panol.

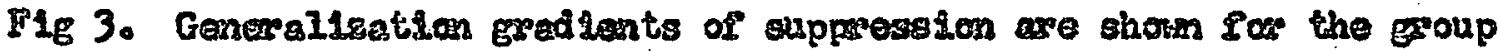
recolving only St troining and $f$ r tho group repolfing St, So training. Tho suppression ratio was obtalned by calculoting $\frac{A}{A+B}$. whese A sares to tho number of respenses during cenersilsetion tosts to the line tilt stimulus superimpered on the St (green) and $B$ refars to tho rumbor of responses smitted dureng generaligation tosts to the St. Comploto suppaseion is Indiostod by 0.00 and no guppression by 0.50. Mapo responses to a line tilt than to the S+ atimalus 18 Indleated by satios greates than 0.50. Generalisation gradients at each

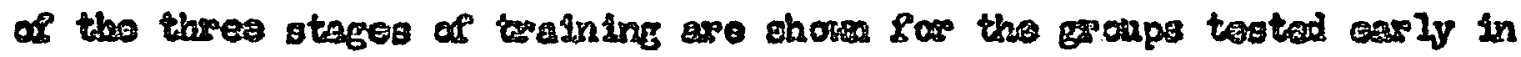
tralning and then zotergted at ach subsequant stage. 
Fig 4. Genesalisation gred lonts of guppession are shown for the group seceiving only St training and Por the group recoiving St. So training. The suppression satlo was obtalned by celouleting $\frac{A}{A+B}$, where $A$ pareirs to the numbor of responges duping genaralization tosts to the lino tilt stimulus suparimposed on tho $5+$ (green) and 8 raters to the number of responsos ontted during Ceneralization tasts to the St. Couplete supprassion is indicated by 0.00 and no suppession by 0.50 . Mose sesponses to a line tilt than to the St stimalus

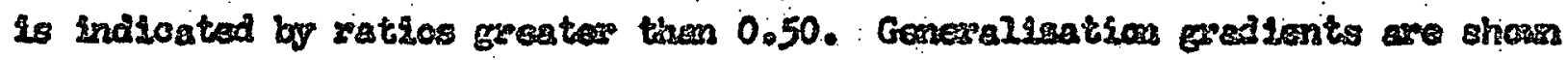
aftor tho middlo and lato stages of tainsing. These groups wase not tostod $\cos 1 y$ in training. 


\section{$=$}

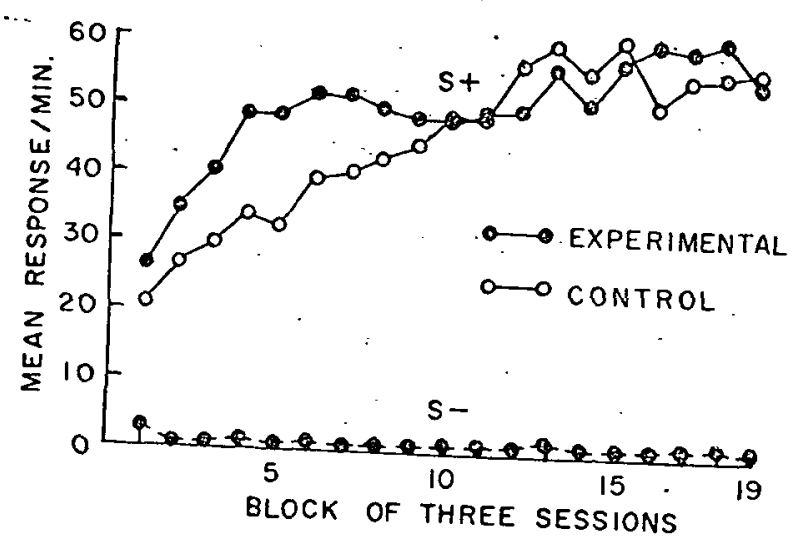

$x$

Figure 1

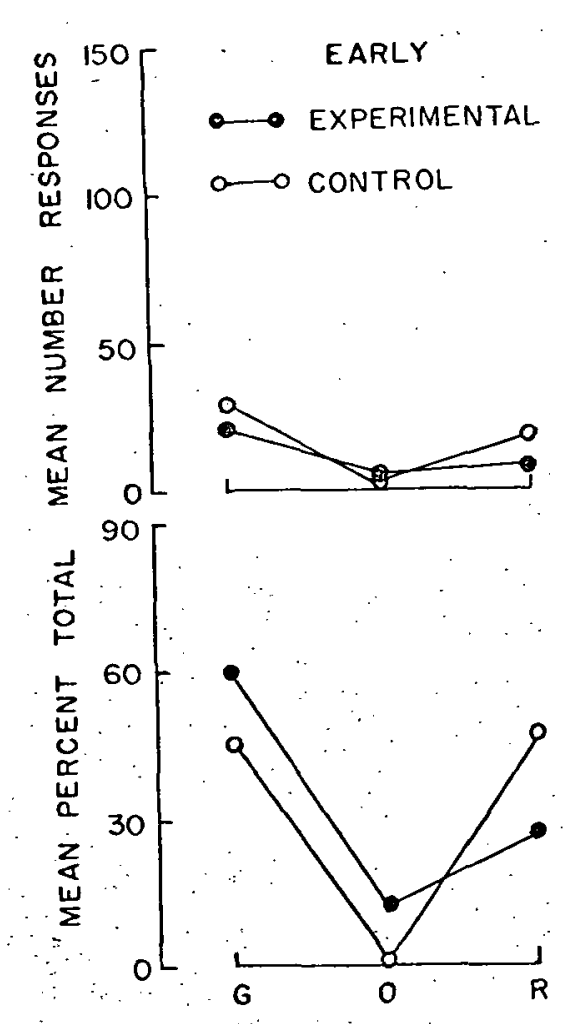

MIDDLE

: LATE 


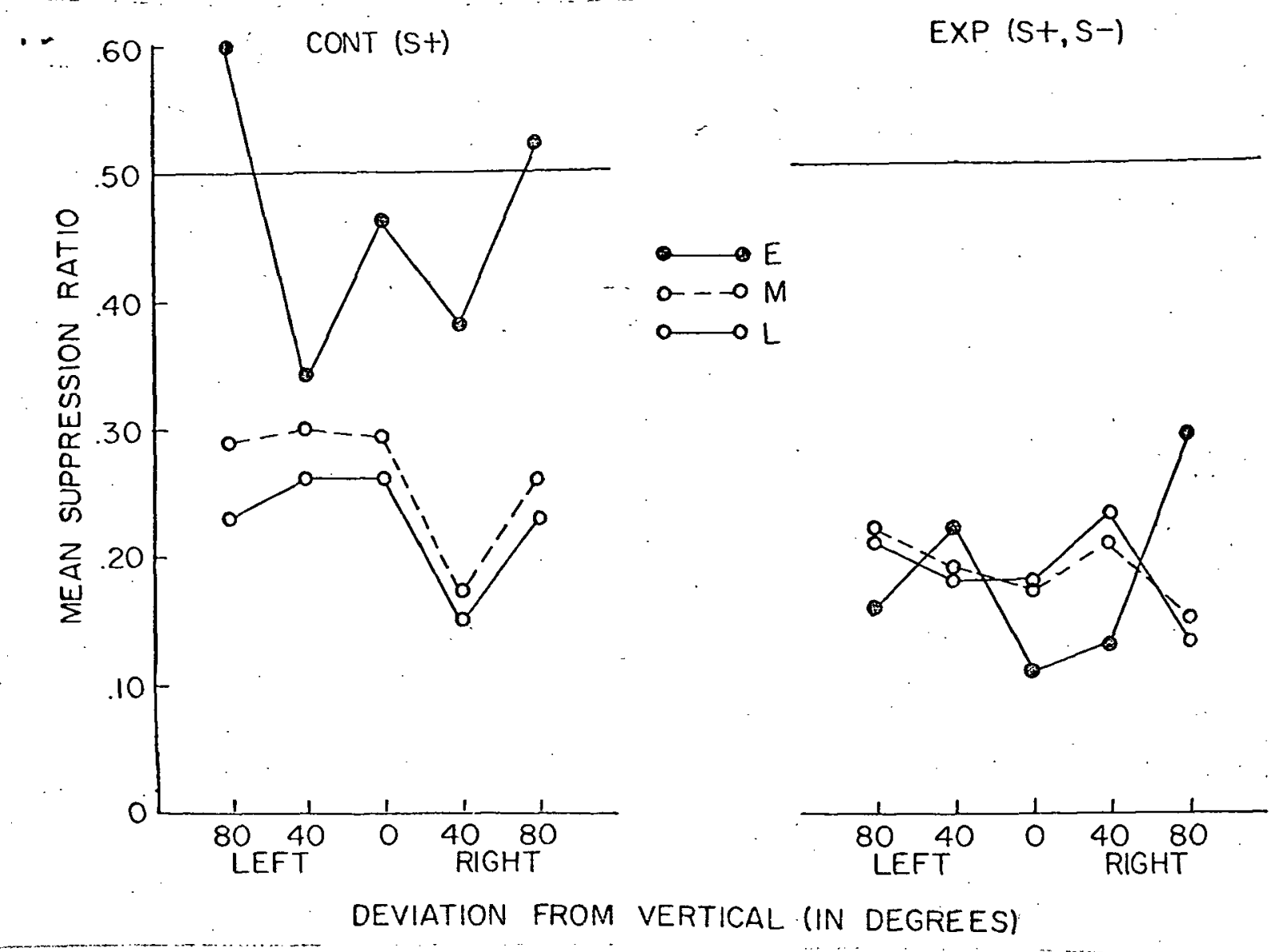

$x$.

Figure 3

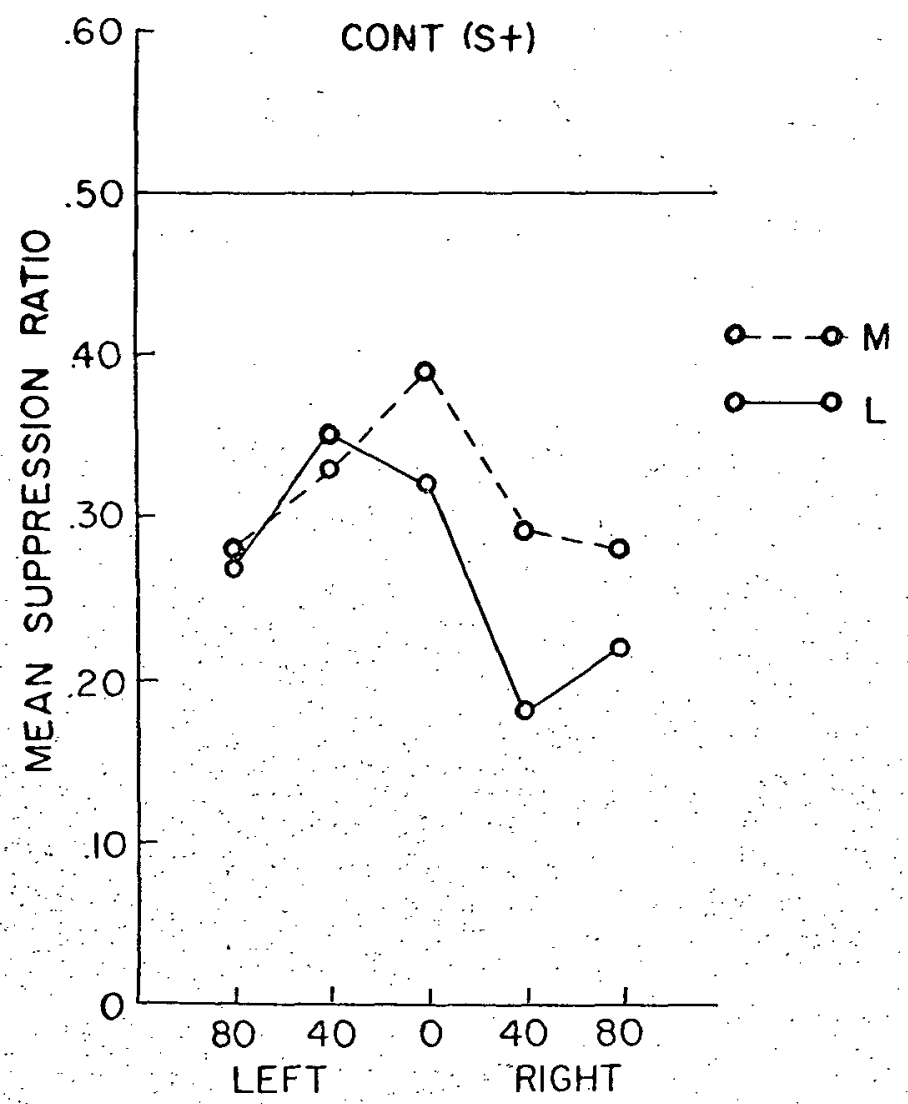

$\operatorname{Exp}\left(s+, s^{-}\right)$

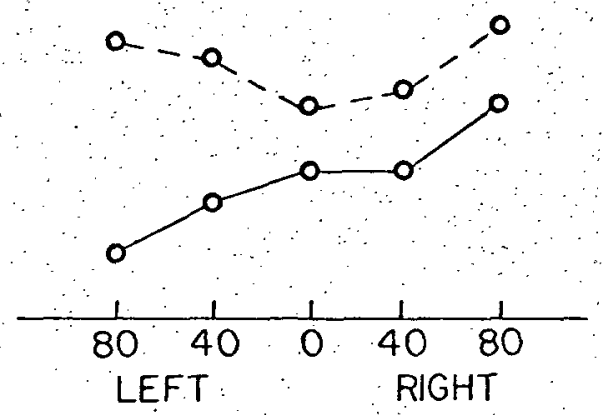

DEVIATION FROM VERTICAL (IN DEGREES) 